\title{
UTILIZATION OF URINE WASTE TO PRODUCE QUALITY CAULIFLOWER
}

\author{
A. Khanal ${ }^{*}$, S. M. Shakya ${ }^{2}$, S. C. Shah ${ }^{2}$, M. D. Sharma ${ }^{3}$
}

\begin{abstract}
A field experiment was carried out at Jamune-1, Gunadi, Tanahun, Nepal on farmer's field during September, 2009 to February, 2010 to test the efficacy of cattle urine from gutter alone and in combination with urea as a potential supplement to nitrogenous fertilizers in improving yield and quality of cauliflower cv. Kathmandu Local. The experiment was laid out in a randomized complete block design with eight treatments; $100 \mathrm{~kg} \mathrm{~N} \mathrm{ha}$ supplied by urea, $100 \mathrm{~kg} \mathrm{~N} \mathrm{ha-1}$ supplied by urine, $125 \mathrm{~kg} \mathrm{~N} \mathrm{ha}^{-1}$ supplied by urine, $75 \mathrm{~kg} \mathrm{~N} \mathrm{ha-1}$ supplied by urine, $50 \mathrm{~kg} \mathrm{~N} \mathrm{ha-1}$ supplied by urine, $100 \mathrm{~kg} \mathrm{~N} \mathrm{ha}^{-1}$ supplied by urea (75 kg) and urine (25 $\mathrm{kg}), 100 \mathrm{~kg} \mathrm{~N} \mathrm{ha-1}$ supplied by urea (50 kg) and urine (50 kg), $100 \mathrm{~kg} \mathrm{~N} \mathrm{ha}^{-1}$ supplied by urea $(25 \mathrm{~kg})$ and urine $(75 \mathrm{~kg})$ having three replications. Application of $125 \mathrm{~kg} \mathrm{~N} \mathrm{ha}^{-1}$ through urine significantly increased vegetative characters. Application of $100 \mathrm{~kg} \mathrm{~N} \mathrm{ha}{ }^{-1}$ through urine significantly increased yield and quality characters as compared to application of either higher or lower dose of urine. Fifty percent substitution of urea by urine produce better morphological, yield and quality character than other combination of urine and urea. The highest curd yield $\left(20.08 t \mathrm{ha}^{-1}\right)$, the best result in sensory evaluation, and the highest benefit cost ratio (5.84) were observed by application of $100 \mathrm{~kg} \mathrm{~N} \mathrm{ha}^{-1}$ through urine.
\end{abstract}

Key words: Nitrogen, organic, substitution, parameter, quality

\section{INTRODUCTION}

Cauliflower (Brassica oleracea L. var. botrytis), queen of the winter vegetables, is commercially grown in Nepal. It covers a total area of 29,836 ha and a total production of 399,012 tones (VDD, 2010). Productivity of cauliflower depends on use of balanced fertilizer (Thakur et al., 1991).

The average application rate of chemical fertilizer in Nepal was $78 \mathrm{~kg}$ nutrient $\mathrm{ha}^{-1}$ in vegetables (MOAC, 2007). Total sale of chemical fertilizers in Nepal was 90,856 million ton in 2006/07 including 30,842 million ton urea (MOAC, 2009) that all are imported. The haphazard use of chemical fertilizers with higher dose in commercial areas is hazardous to human health and environment. Health conscious consumers are ready to pay premium price for organic product but its availability does not meet the ever-increasing demand.

Nitrogen is the most limiting major nutrient in mid hills of Nepal. Large amount of nitrogen rich cattle urine is being wasted in the rural Nepal, which can be used as an organic substitute of chemical fertilizers for higher crop production. Average nutrients available in the cattle urine are $4.0 \mathrm{~g}$ ammonium nitrogen $\left(\mathrm{NH}_{4}{ }^{+}-\mathrm{N}\right), 0.2 \mathrm{~g}$ phosphate $\left(\mathrm{P}_{2} \mathrm{O}_{5}\right), 8.0 \mathrm{~g}$ potassium $\left(\mathrm{K}_{2} \mathrm{O}\right), 0.1 \mathrm{~g}$ calcium oxide, $0.2 \mathrm{~g}$ magnesium oxide, $4.0 \mathrm{~g}$ chloride ion associated with salts, $2.0 \mathrm{~g}$ sulphate per liters of urine (Belie et al., 2000).

Neither the chemical fertilizers alone nor organic sources exclusively can achieve the production sustainability of soil as well as crops under high intensive cropping systems (Singh and Yadhav, 1992). In Nepal, farmers pay good attention for collection and utilization of cowdung but little or no attention has been given in collection and utilization of urine. The nutrient content in urine, specially nitrogen, is much higher than other locally

\footnotetext{
${ }^{1}$ Fruit dev. off., Dry Fruit Dev. Centre, Baitadi, Nepa; arunkhanaliaas@yahoo.com

2 Prof., Dept. Soil Sc., Institute of Agriculture and Animal Science, Nepal

${ }^{3}$ Ass. Prof., Dept. of Hort., IAAS, Nepal
} 
available manures. Therefore, Use of cattle urine alone or in combination with chemical fertilizer can increase the productivity of soil and crop.

\section{OBJECTIVES}

To increase economic status of mid-class farmer and produce healthy produce

To sustain the productivity of crop and fertility of soil through utilization of local resources

To assess the effect of urine on yield and quality cauliflower and quantifying the amount of urine for substituting chemical fertilizers

\section{MATERIALS AND METHODS}

The experiment was conducted during September, 2009 to February 2010 in the farmers' field at Jamune VDC, Ward No. 1, Tanahun having sandy loam textured soil with $6.20 \mathrm{pH}$, $1.47 \%$ organic matter, $0.06 \%$ available nitrogen, $85.43 \mathrm{~kg}$ available phosphorus ha ${ }^{-1}$ and $298.67 \mathrm{~kg}$ available potassium ha-1. The mean maximum temperature (26.070C), minimum temperature $(13.970 \mathrm{C})$, relative humidity $(84.98 \%)$ and rainfall were $(6.664 \mathrm{~mm})$ during the crop growing season. The experiment was laid out in a randomized complete block design with eight treatments; $N_{100 k g U r e a}\left(217.37 \mathrm{~kg}\right.$ urea ha $\left.{ }^{-1}\right), N_{125 k g u r i n e}\left(25,510.20\right.$ liter urine ha- $\left.{ }^{-1}\right)$, $N_{100 k g u r i n e}(20,408.16$ liter urine ha-1 $), N_{75 k g u r i n e}(15,306.12$ liter urine ha-1 $), N_{50 k g u r i n e}(10204.08$ liter urine $\left.\mathrm{ha}^{-1}\right), \mathrm{N}_{75 \mathrm{kgurea}+25 \mathrm{kgurine}}\left(163.04 \mathrm{~kg}\right.$ urea ha ${ }^{-1}+5,102.04$ liter urine $\left.\mathrm{ha}^{-1}\right)$, N50kgUrea+ ${ }_{50 \mathrm{kgurine}}\left(108.70 \mathrm{~kg}\right.$ urea ha ${ }^{-1}+10204.08$ liter urine ha $\left.{ }^{-1}\right), \mathrm{N} 25 \mathrm{kgUrea}^{-1}{ }_{75 \mathrm{kgurine}}(54.35$ $\mathrm{kg}$ urea ha-1 $+15,306.12$ liter urine ha-1) and three replications. The total experimental area was $383.85 \mathrm{~m} 2(29.5 \mathrm{~m} \times 13.0 \mathrm{~m})$ with an individual plot size of $3 \mathrm{~m} \times 3 \mathrm{~m}$ i.e. $9 \mathrm{~m} 2$. Planting of 37 days old seedling of cauliflower cultivar Kathmandu local was done at the crop geometry of $(60 \times 60) \mathrm{cm} 2$. Basis of fertilizer calculation was 100:60:40 kg NPK ha-1. Well decomposed farmyard manure was applied @ of $6.56 \mathrm{t} / \mathrm{ha}, 15$ days before transplanting to enhance soil physical properties. Phosphorous and potash were applied at the time of transplanting. Urea was applied as per treatment description in which half dose was applied at the time of transplanting and remaining was top-dressed equally at 30 and 60 days after transplanting. Urine was collected in the plastic drum from gutter and tested in laboratory for NPK content. Average nutrient content of cattle urine collected was $0.49 \%$ total Nitrogen (Kjeldhal digestion), 3.243 $\mathrm{g} \mathrm{I} \mathrm{l}^{-1}$ total phosphorous (Spectrophotometer), 0.483\% total potassium (Atom Absorption Spectrophotometer) and $7.3 \mathrm{pH}$. Urine was applied as per treatment description, $5 \mathrm{~cm}$ away from plant stem for 6 times in 1:1 dilution with water at 14 days interval (i.e. $0,14,28,42,56$ and 70 days after transplantation). Observations on various vegetative, reproductive and quality parameters were recorded. Analysis of variance for all parameters was done using statistical analysis through MSTAT-C programme. All the analyzed data were subjected to DMRT for mean separation at $5 \%$ level of significance.

\section{RESULTS AND DISCUSSION}

\section{EFFECTS ON GROWTH PARAMETERS OF CAULIFLOWER}

The highest plant heights, the highest stem diameter, the highest numbers of leaf per plants, the highest leaf area per plants, the highest biological yield were found in the treatment $\mathrm{N}_{125 \mathrm{~kg} u r i n e}$. Whereas, the lowest stem height, the lowest stem diameter, the lowest numbers of leaf per plant, the lowest leaf area per plants, the lowest biological yield were observed in the treatment $\mathrm{N}_{50 \mathrm{~kg} g r i n e}$.

\section{EFFECTS ON CURD WEIGHT AND YIELD}

The highest curd weight $\left(722.8 \mathrm{~g} \mathrm{plant}^{-1}\right)$ obtained from $\mathrm{N}_{100 \mathrm{kgurine}}$ was significantly greater than that from $\mathrm{N}_{100 \mathrm{kgurea}}($ Table 1). Fifty-percentage substitution of urea by urine produce higher curd yield $\left(688.7 \mathrm{~g}\right.$ plant $\left.^{-1}\right)$ than $25 \%$ and $75 \%$ substitution of urea by urine. The 
highest curd yield $\left(20.08 \mathrm{t} \mathrm{ha}^{-1}\right)$ was obtained from $\mathrm{N}_{100 \mathrm{kgurine}}$, greater than curd yield $(17.86 \mathrm{t}$ $\mathrm{ha}^{-1}$ ) from $\mathrm{N}_{100 \mathrm{kgurea}}$. The highest curd yield $\left(20.08 \mathrm{t} \mathrm{ha}^{-1}\right)$ was obtained from $100 \%$ substitution of urea by urine followed by $50 \%$ substitution $\left(19.13 \mathrm{t} \mathrm{ha}^{-1}\right)$, both being at par with each other. The lowest yield was in $\mathrm{N}_{125 \mathrm{kgurine}}$ and $\mathrm{N}_{50 \mathrm{kgurine}}\left(13.04\right.$ and $13.51 \mathrm{t} \mathrm{ha}^{-1}$, respectively), both being at par. Yield at $50 \%$ substitution of urea by urine was higher than $25 \%$ and $75 \%$ substitution.

Higher yield in urine supplied plot might be due to greater availability of different essential nutrient elements and hormones from cattle urine at various growth stages of cauliflower. Increased in yield of bitter gourd by the application of cattle urine was also reported by SSM-P (2009). Excessive application of urine causes death of new leaves and produced small firm curds, which might be due to luxuriant vegetative growth. Everaarts (1994) also reported that excessive application of nitrogen reduced marketable yield of cauliflower along with detrimental effects on harvest quality.

\section{EFFECTS ON TASTE, COLOR AND COMPACTNESS OF CURD}

The most appreciable tasty curd (7.933) was recorded in the treatment $N_{100 k g u r i n e}$ and the poorest taste of curd (4.567) was recorded in the treatment $\mathrm{N}_{100 \mathrm{~kg} u r e a}$ (Table 1). Application of urine increased the taste of curd while excess urine decreased its taste.

The application of urine in optimum quantity promoted good color in the curd while heavy supply of nitrogen resulted in poor color appearance. Brown curd by high nitrogen supply was reported by Everaarts (1994).

Table 1. Effects of urine, urea and their combination on curd characteristics of cauliflower at Jamune VDC, Gunadi, Tanahun, Nepal (2009/10)

\begin{tabular}{|c|c|c|c|c|c|}
\hline Treatments & $\begin{array}{l}\text { Curd weight } \\
\text { (g plant }^{-1} \text { ) }\end{array}$ & $\begin{array}{l}\text { Curd yield } \\
\left(\mathrm{t} \mathrm{ha}^{-1}\right)\end{array}$ & $\begin{array}{l}\text { Taste } \\
(1-9)\end{array}$ & $\begin{array}{l}\text { Color } \\
(1-9)\end{array}$ & $\begin{array}{l}\text { Compactness } \\
(1-9)\end{array}$ \\
\hline $\mathrm{N}_{100 k g u r e a}$ & $643.1^{b}$ & $17.86^{\mathrm{b}}$ & $4.567^{\mathrm{e}}$ & $5.267^{b}$ & $7.133^{a}$ \\
\hline$N_{100 k g U r i n e}$ & $722.8^{a}$ & $20.08^{a}$ & $7.933^{\mathrm{a}}$ & $7.200^{\mathrm{a}}$ & $7.233^{\mathrm{a}}$ \\
\hline $\mathrm{N}_{125 \mathrm{~kg} \text { urine }}$ & $469.6^{d}$ & $13.04^{d}$ & $7.833^{a b}$ & $5.700^{\mathrm{ab}}$ & $5.033^{c}$ \\
\hline $\mathrm{N}_{75 \mathrm{~kg} U \mathrm{rine}}$ & $635.9^{b c}$ & $17.66^{b c}$ & $7.333^{b c}$ & $5.733^{a b}$ & $6.467^{\mathrm{ab}}$ \\
\hline$N_{50 k g u r i n e}$ & $486.3^{d}$ & $13.51^{\mathrm{d}}$ & $6.867^{c}$ & $6.067^{a b}$ & $5.767^{\mathrm{bc}}$ \\
\hline $\mathrm{N}_{75 \mathrm{~kg} \text { Urea+25kgUrine }}$ & $581.0^{c}$ & $16.14^{c}$ & $4.967^{\mathrm{e}}$ & $5.667^{a b}$ & $6.467^{\mathrm{ab}}$ \\
\hline$N_{50 k g U r e a+50 k g U r i n e}$ & $688.7^{\mathrm{ab}}$ & $19.13^{a b}$ & $5.600^{d}$ & $6.067^{a b}$ & $6.867^{\mathrm{ab}}$ \\
\hline $\mathrm{N}_{25 \mathrm{~kg} \text { Urea+75kgurine }}$ & $634.3^{b c}$ & $17.62^{b c}$ & $6.933^{c}$ & $5.967^{a b}$ & $6.733^{a b}$ \\
\hline Mean & 607.081 & 16.881 & 6.504 & 5.958 & 6.463 \\
\hline LSD 0.05 & 55.38 & 1.543 & 0.5136 & 1.393 & 1.999 \\
\hline SEm \pm & 1000.081 & 0.776 & 0.086 & 0.633 & 0.469 \\
\hline CV (\%) & 5.22 & 5.22 & 4.51 & 13.35 & 10.60 \\
\hline
\end{tabular}

Means followed by the same letter (s) in the column are not significantly different at $5 \%$ level as determined by DMRT. Notation 1-9 in hedonic scale denotes 9 as the highest and las the lowest rating.

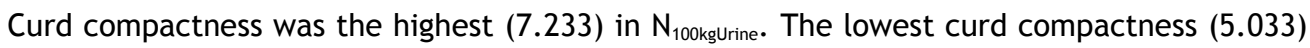
in $\mathrm{N}_{125 \mathrm{~kg} u r i n e}$ was in agreement with curd compactness (5.767) in $\mathrm{N}_{50 \mathrm{~kg} u \text { rine }}$ (Table 1). Application of higher or lower dose of urine decreased the curd compactness. Higher compactness of curd might be due to optimum growth of curd in $\mathrm{N}_{100 \mathrm{~kg} u \text { rine }}$ due to supplement of required 
nitrogen and other mineral elements required for the plant growth. Poor compactness of curd at $N_{125 k g u r i n e}$ might be due to overgrowth of vegetative part and smaller curd with poor growth.

The consumers' acceptability increased as the level of nitrogen supplied from urine increases upto $\mathrm{N}_{100 \mathrm{kgurine}}$ but over dose of urine $\mathrm{N}_{125 \mathrm{~kg} u \text { rine }}$ and use of chemical fertilizers lowers the overall acceptability of curd.

\section{EFFECTS ON VITAMIN C CONTENT}

The highest vitamin $C$ content $(66.96 \mathrm{mg} / 100 \mathrm{~g})$ of cauliflower curd was in $\mathrm{N}_{50 \mathrm{~kg} u r i n e}$. The

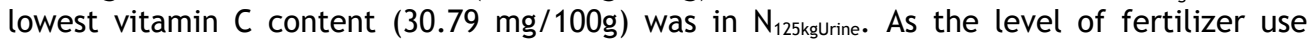
increased accumulation of higher amount of nitrate in plant tissue inhibits the production of vitamin C (Lisiewska and Kmiecik, 1996).

\section{PHYSICO-CHEMICAL PROPERTIES OF SOIL AFTER HARVEST}

The soil $\mathrm{pH}$ increased with the application of urine but the application of urea leads to decreased in $\mathrm{pH}$ (Table 2). Similar result of decreasing $\mathrm{pH}$ and acidification of soil by addition of chemical fertilizer was reported by Rowell and Wild (1985). Application of urine increases $\mathrm{pH}$ in pearl millet field was reported by Powell et al. (1998). $\mathrm{N}_{125 \mathrm{~kg} \text { urine increased }}$ the organic matter content in soil. The amount of soil available nitrogen and potassium increased with the application of urine. The soil available phosphorus increased compared to before harvest and its availability increased with increase application of urine. Similar result of increased availability of phosphorous and its subsequent uptake by pearl millet after application of cattle urine was reported by Powell et al., 1998. These results are due to the fact that urine contains nitrogen along with potassium. Urine increased the soil $\mathrm{pH}$ which may leads to higher $P$ availability. The soil texture was sandy loam.

Table 2. Physico-chemical properties of soil after the treatments at Jamune VDC, Gunadi, Tanahun, Nepal (2009/10)

\begin{tabular}{|c|c|c|c|c|c|c|}
\hline \multirow[b]{2}{*}{ Treatments } & \multicolumn{6}{|c|}{ Details } \\
\hline & Soil $p^{H}$ & $\begin{array}{l}\text { Organic } \\
\text { Matter (\%) }\end{array}$ & $\begin{array}{l}\text { Available } \\
\mathrm{N}(\%)\end{array}$ & $\begin{array}{l}\text { Available } \\
\mathrm{P}\left(\mathrm{kg} \mathrm{ha}^{-1}\right)\end{array}$ & $\begin{array}{l}\text { Available } \\
\mathrm{K}\left(\mathrm{kg} \mathrm{h}^{-1}\right)\end{array}$ & Texture \\
\hline$N_{100 k g U r e a}$ & 6.097 & 1.040 & 0.047 & 94.233 & 245.83 & SL \\
\hline$N_{100 k g U r i n e}$ & 6.730 & 1.273 & 0.060 & 127.47 & 417.57 & SL \\
\hline $\mathrm{N}_{125 \mathrm{kgUrine}}$ & 6.583 & 1.637 & 0.080 & 132.67 & 419.56 & SL \\
\hline $\mathrm{N}_{75 \mathrm{~kg} U \mathrm{urine}}$ & 6.650 & 1.177 & 0.053 & 98.10 & 321.91 & SL \\
\hline$N_{50 k g u r i n e}$ & 6.533 & 1.137 & 0.053 & 112.77 & 210.32 & SL \\
\hline $\mathrm{N}_{75 \mathrm{~kg} U \text { rea }+25 \mathrm{~kg} \text { urine }}$ & 6.187 & 1.107 & 0.047 & 76.93 & 233.68 & SL \\
\hline $\mathrm{N}_{50 \mathrm{~kg} U \text { rea }+50 \mathrm{~kg} \text { urine }}$ & 6.427 & 1.253 & 0.060 & 95.767 & 254.16 & SL \\
\hline $\mathrm{N}_{25 \mathrm{~kg} \text { grea }+75 \mathrm{~kg} U \text { rine }}$ & 6.423 & 1.283 & 0.060 & 122.36 & 311.95 & SL \\
\hline
\end{tabular}

Source: Soil Science Laboratory, DOA, Hetauda,

Note: $\mathrm{SL}=$ Sandy Loam, $\mathrm{N}=$ Nitrogen, $\mathrm{P}=$ Phosphorus and $\mathrm{K}=$ Potassium

\section{EFFECTS ON COSTS OF PRODUCTION, NET RETURN AND BENEFIT COST RATIO}

The highest total cost of production (NRs. 108,229) was in $\mathrm{N}_{125 \mathrm{~kg} u r i n e}$ and the lowest total cost of production (NRs. 80,203) was in $\mathrm{N}_{100 \mathrm{~kg} u r e a .}$ 
Table 3. Benefit cost ratio of cauliflower production by using different level of urine, urea and their combination at Jamune VDC, Gunadi, Tanahun, Nepal $(2009 / 10)$

\begin{tabular}{|c|c|c|c|c|c|c|}
\hline Treatments & $\begin{array}{l}\text { Curd Yield (Kg } \\
\left.\mathrm{ha}^{-1}\right)\end{array}$ & $\begin{array}{l}\text { Price (Rs } \\
\mathrm{kg}^{-1} \text { ) }\end{array}$ & $\begin{array}{l}\text { Gross Income } \\
\text { (NRs.) }\end{array}$ & $\begin{array}{l}\text { Total cost } \\
\text { (NRs.) }\end{array}$ & $\begin{array}{l}\text { Net } \\
\text { Return } \\
\text { (NRs.) }\end{array}$ & $\begin{array}{l}\mathrm{B} / \mathrm{C} \\
\text { ratio }\end{array}$ \\
\hline $\mathrm{N}_{100 \mathrm{~kg} \text { Urea }}$ & 17862.8 & 15 & 267,942 & 80,203 & 187,739 & 3.34 \\
\hline$N_{100 k g u r i n e}$ & 20079.25 & 30 & 602,376 & 103,229 & 499,147 & 5.84 \\
\hline $\mathrm{N}_{125 \mathrm{~kg} \text { urine }}$ & 13044.99 & 30 & 391,350 & 108,391 & 282,959 & 3.61 \\
\hline$N_{75 k g u r i n e}$ & 17664.02 & 30 & 529,920 & 98,127 & 431,793 & 5.40 \\
\hline$N_{50 k g u r i n e}$ & 13508.98 & 30 & 405,270 & 93,025 & 312,245 & 4.36 \\
\hline $\mathrm{N}_{75 \mathrm{~kg} \text { Urea+25kgurine }}$ & 16139.4 & 20 & 322,788 & 93,510 & 229,278 & 3.45 \\
\hline $\mathrm{N}_{50 \mathrm{~kg} U \mathrm{rea}+50 \mathrm{~kg} \text { Urine }}$ & 19130.68 & 20 & 382,614 & 97,416 & 285,198 & 3.93 \\
\hline $\mathrm{N}_{25 \mathrm{~kg} \text { Urea+75kgurine }}$ & 17619.57 & 20 & 252,392 & 101,322 & 251,070 & 3.48 \\
\hline
\end{tabular}

Urine was locally available resources, which was obtained at the rate of Rs. one per liter. People were ready to pay higher cost if cauliflower is grown organically and if they found it has better taste. Cauliflower from only urine used treatments was sold on average of NRs. $30 \mathrm{~kg}^{-1}$ after that. Consumer perception towards the product from both urine and urea used treatments was poor and pay NRs. $20 \mathrm{~kg}^{-1}$. Consumers pay NRs. $15 \mathrm{~kg}^{-1}$ for cauliflower from only urea used treatments. The highest net return (NRs. 499,147) was obtained from 20408.16 liter urine ha-1. The lowest net return (NRs. 229,278) was from $163.04 \mathrm{~kg}^{-1}$ urea ha-1 supplemented with 5120.04 liter urine ha ${ }^{-1}$. B : C ratio was the highest (5.84) from 20408.16 liter urine $\mathrm{ha}^{-1}$ and the lowest $\mathrm{B}: \mathrm{C}$ ratio (3.34) ratio was found in $217.37 \mathrm{~kg}$ urea ha ${ }^{-1}$. B : C ratio was higher (3.93) for $50 \%$ supplement of urea by urine than other supplements.

\section{CONCLUSIONS}

Although all the growth parameters recorded in the treatment $\mathrm{N}_{125 \mathrm{~kg} \text { urine }}$ were greater than other treatments, yield and quality parameters recorded in the treatment $\mathrm{N}_{100 \mathrm{~kg} u \text { rine }}$ were best followed by parameters recorded in the treatment N50kgUrea+ ${ }_{50 \mathrm{~kg} u r i n e}$. The highest curd yield $\left(20.08 \mathrm{t} \mathrm{ha}^{-1}\right)$ was recorded in $100 \%$ substitution of urea by urine $\left(\mathrm{N}_{100 \mathrm{~kg} u r i n e}\right)$ followed by $50 \%$ substitution of urea by urine $\left(19.13 \mathrm{t} \mathrm{ha}^{-1}\right)$, both being at par with each other. The lowest yield was obtained from $\mathrm{N}_{125 \mathrm{~kg} u r i n e}$ and $\mathrm{N}_{50 \mathrm{~kg} u \text { rine }}\left(13.04\right.$ and $13.51 \mathrm{t} \mathrm{ha}{ }^{-1}$, respectively), both being at par. Yield at 50\% substitution of urea by urine was higher than $25 \%$ and $75 \%$ substitution of urea by urine. B: C ratio was the highest (5.84) in the treatment $N_{100 k g u r i n e}$ and the lowest $B: C$ ratio (3.34) ratio was found in the treatment $N_{100 k g u r e a}\left(217.37 \mathrm{~kg}_{\text {urea ha }}{ }^{-1}\right)$. B : C ratio was higher (3.93) for $50 \%$ supplement of urea by urine than other supplements. Cattle urine yielded better and produces higher $B$ : $C$ ratio than urea along with improving soil properties. Cauliflower growers might be benefited by the use of cattle urine alone or in combination with urea to reduce the urea requirement and to obtain better yield and quality. Thus, we suggest to promote the conservation and use of urine through different extension activities, (training, demonstation and subsidy for cowshed improvement) for import subsititution of chmemical fertilizer and for better production, economy and healthy produce.

\section{REFERENCES}

Belie, N. D., M. Richardson, C. R. Braam, B. Svennerstedt, J. J. Lenehan and B. Sonck, 2000. Durability of building materials and components in the agricultural environment. J. Agro-Engineering Res., 75:225-24.

Everaarts, A. P, 1994. Nitrogen fertilization and head rot in broccoli. Neth. J. Agric. Sci., 42:195-201. 
Lisiewska, Z. and W. Kmiecik, 1996. Effects of level of nitrogen fertilizer, processing conditions and period storage of frozen broccoli and cauliflower on vitamin C retention. Food Chemistry 57(2):267-270.

MOAC, 2007. Statistical information on Nepalese Agriculture 2006/07. Ministry of Agriculture and Cooperatives. Government of Nepal. Kathmandu.

MOAC, 2009. Selected Indicators of Nepalese Agriculture and Population. Ministry of Agriculture and Cooperatives, agri-Business Promotion and Statistics Division/Gender Equity and Environment Division. Government of Nepal. Singh Durbar. Kathmandu.

Powell, J. M., F. N. Ikpe, Z. C. Somda and S. Fernandez-Rivera, 1998. Urine effects on soil chemical properties and the impact of urine and dung on pearl millet yield. Expl. Agric., 34:259-276.

Rowell D. L. and A. Wild, 1985. Cause of soil acidification: a summary. Soil Use and Management, 1:3233.

Singh, G. B. and D. V. Yadhav, 1992. Integrated nutrient supply system in sugarcane and sugarcane based cropping system. Fert. News, 37:15-22.

SSMP, 2009. Farmer profiles from the mid-hills of Nepal. The Sustainable Soil Management Programme, Helvitas, Nepal.

VDD, 2010. Annual report. Vegetable Development Division, Department of Agriculture, Government of Nepal. Khumaltar, Lalitpur, Nepal. 